\title{
Sikap Muslim Terhadap Modernitas: Kasus Gerakan Khilafatul Muslimin di Lampung
}

\author{
Ilham Mundzir \\ Fakultas Agama Islam, Universitas Pof. Dr. HAMKA, Jakarta dan \\ Email: ilham2_m@yahoo.com
}

\begin{abstract}
The relationship between Islam, or Muslim societies, and modernity has always become interesting issue to discuss. This is partly because, as predicted in certain theory of modernization, the role and significance of religion in modern society will decrease. Yet, the above claim is no longer relevant to the current situation where sociologically, religions has still survived and has even increasingly become societal needs. Islamic societies have often utilized religious symbols in order to fight against modernization and its extended issues, including secularization, democracy, gender equality, and the like. This article is an attempt to present the current response of Muslim societies to modernity. By way of case study, it elaborates on the experience of the Khilafatul Muslimin, a fundamentalist Movement that uses religious teachings as a soursce to create a new world order. Keywords: Islam, modernity, fundamentalism, Khilafatul Muslimin
\end{abstract}

\section{ABSTRAK}

Bagaimana seharusnya relasi antara Islam, lebih tepatnya respon Muslim, dan modernitas semakin menarik diperdebatkan. Pasalnya, sebagaimana diramalkan oleh tesis dan teori modernisasi, agama akan kehilangan peran dan kekuatannya di dalam masyarakat modern. Klaim-klaim itu kini terbukti semakin tak lagi relevan. Secara sosiologis, agama tetap bertahan, hidup, dan bahkan menjelma jadi kebutuhan penting bagi banyak masyarakat. Bahkan, tak jarang, dengan menggunakan bahasa serta simbol agama, masyarakat Muslim kerap tampil melawan konsep-konsep modernisasi dan berbagai turunannya seperti sekularisasi, demokrasi, kesetaraan gender, dan sebagainya yang oleh sebagian telah ditahbiskan sebagai ideologi yang final. Menjadikan Khilafatul Muslimin sebagai kajiannya, tulisan ini menunjukkan bagaimana agama justru berperan penting sebagai inspirasi dan sumber ide bagi kelompok-kelompok fundamentalis Muslim untuk membangun tatanan masyarakat dan dunia yang sepenuhnya berbeda. Kata kunci: Islam, modernitas, fundamentalisme, dan Khilafatul Muslimin

\section{PENDAHULUAN}

Bagi para pendukung teori modernisasi, mengikuti arus logika Max Weber dan nama-nama lainnya, ada keyakinan bahwa dunia berkembang ke arah yang semakin modern yang antara lain ditandai dengan rasionalisasi, sekularisasi dan sebagainya. Menurut teori ini, agama adalah fenomena "tradisional" yang pada akhirnya akan menurun, termarjinalisasi oleh proses modernisasi, industrialisasi, urbanisasi, dan pendidikan yang masif. ${ }^{1}$ Begitulah bunyi hukum teori modernitas. Sosiolog seperti Bryan Wilson dalam Contemporary 
Transformation of Religion (1976) misalnya dengan sangat percaya diri menyebut bahwa modernisasi akan membuat agama kehilangan tempat dan peranannya di dalam masyarakat. Yang mutakhir, terdapat Pippa Norris dan Ronald Inglehart yang dengan riset kuantitatifnya menyurvei nilai-nilai masyarakat dunia. Keduanya, seraya mempertahankan argumen modernisasi di atas, menyebut bahwa pertumbuhan ekonomi, tingkat sosial-ekonomi dan pembangunan manusia saat ini telah dan pada jangka panjangnya akan memunculkan sekularisme, membawa kepada erosi nilai-nilai keagamaan, keimanan dan praktik keagamaan. ${ }^{2}$ Agama dan modernitas tidak mungkin bersatu (they just don't mix!). Pendeknya, agama secara tak terelakkan akan terlempar dari setiap masyarakat maju yang modern.

Faktanya, kini semakin banyak fenomena yang bisa menantang asumsi dan tesis di atas tersebut. Membantah pelbagai klaim-klaim modernitas menyangkut hilangnya agama, Juergensmeyer menegaskan bahwa saat ini dunia sedang dilanda krisis kepercayaan terhadap nasionalisme sekuler yang banyak dilancarkan oleh para agamawan religius dari beragam agama, termasuk Islam di dalamnya. ${ }^{3}$ Senada dengan itu, Charles Davis justru membuktikan bahwa agama saat ini kian merupakan kekuatan penting dalam seluruh aspek kehidupan modern ini baik dalam bidang ekonomi, sosial, politik, dan budaya. ${ }^{4}$ Dalam kasus di Indonesia saja misalnya ekonomi Islam merupakan tren yang terus tumbuh. Bank-bank konvensional bahkan bank asing pun kini berlomba-lomba mengembangkan lini perbankan syariah. Dalam konteks budaya, busana muslimah kini menjadi gaya hidup. Majalah-majalah fesyen Muslimah tumbuh bak jamur di musim hujan. Demikian juga pameran busana muslimah. Di luar itu, organisasi-organisasi keagamaan juga banyak bermunculan, yang sampai pada tahap tertentu bisa menegaskan meningkatnya kesalehan dan religiusitas masyarakat.

Agama merupakan salah satu tema perdebatan yang menarik diperbincangkan dalam hubungannya dengan segala perkembangan modernitas. Sebagaimana diungkapkan oleh Gilles Kepel, dalam sepertiga akhir abad ini, dunia menyaksikan kemunculan seruan serta gerakan-gerakan kembali kepada agama dalam cara-cara yang tak terduga sebelumnya. Sebuah pendekatan keagamaan baru muncul dan menemukan bentuknya, yang tidak lagi bertujuan untuk menyesuaikan pada nilai-nilai modern yang sekular, tetapi pada penemuan kembali suatu landasan suci bagi masyarakat. Diungkapkan dalam banyak cara, gerakan tersebut pada dasarnya berupaya untuk menentang modernitas yang dianggap gagal, mengalami jalan buntu serta menjadikan manusia terpisah jauh dari Tuhan. ${ }^{5}$

Indonesia memberikan fakta menarik soal ini. Berbarengan dengan gerakan reformasi, kita dipertontonkan dengan kemunculan gerakan-gerakan keagamaan yang menyerukan pentingnya penerapan syariat Islam secara formal dalam negara seperti Front Pembela Islam (FPI), Hizbut Tahrir, Majelis Mujahidin Indonesia, Jamaah Anshorut-Tauhid, Forum Umat Islam, Komite Persiapan Penegakan Syariat Islam (KPPSI), Laskar Jihad dan Khilafatul Muslimin. Oleh karena itu, tak mengherankan bila meskipun Michael Burleigh menyebut abad ini sebagai age of reason yang menjadi ruh utama modernitas, namun pada saat yang bersamaan juga disebut sebagai century of faiths atau age of faiths. ${ }^{6}$ 
Hubungan antara agama Islam dan modernitas atau lebih tepatnya respon Muslim ${ }^{7}$ terhadap modernitas tidaklah monolitik melainkan beragam. Ada juga yang menganggap keduanya bisa berjalan dengan seiringan dan saling match di antara keduanya. Asghar Ali Enginer misalnya mengatakan bahwa tak ada kesulitan serius yang tidak dapat diatasi antara Islam sebagai agama dan pandangan hidup dengan dunia modern kita ini. ${ }^{8}$ Pandangan semacam ini tidak hanya dikemukakan oleh sarjana Muslim saja, melainkan juga disuarakan oleh para sarjana Barat seperti Ernest Gellner dan Mark Woodward. ${ }^{9}$ Meskipun demikian, banyak pula yang menilai keduanya tidak kompatibel, mismatch dan bahkan cenderung problematik. Sayyid Quthub merupakan tokoh berpengaruh yang menilai kemodernan tidak akan pernah bisa berdampingan karena ia identik dengan kejahiliyahan. ${ }^{10}$ Sejauh ini tidak konsensus yang muncul yang mengikat mengenai bagaimana seharusnya komunitas Muslim bersikap terhadap modernitas.

Sosiolog seperti Bellah, umpamanya, dengan sangat baik menjelaskan bahwa upaya-upaya masyarakat Muslim dalam menghadapi modernitas sesungguhnya sangat beragam. Hal ini lantaran secara sosiologis, persoalannya, lanjut Bellah, bukan hanya terletak pada pertanyaan apakah Islam kompatibel dengan modernitas atau tidak. Mengingat agama adalah cara untuk memahami dunia, maka persoalan yang paling besar dan mendasar bagi Muslim saat ini adalah bagaimana Islam dapat secara efektif memenuhi kebutuhan keagamaan/ religiusitas bagi mereka sendiri. ${ }^{11}$ Beranjak dari situ, bentuk serta ekspresi keberagamaan masyarakat Muslim menjadi sangat beragam, dipengaruhi oleh konteks-konteks tertentu. Kita bisa menemukan ada agama rakyat, sufisme, Islam kultural, fundamentalisme, liberalisme, dan sebagainya. Dengan bahasa lain, Bambang Pranowo menjelaskan bahwa interaksi dan dialog antara agama dengan manusia beserta kebudayaan yang melingkupinya akan banyak menghasilkan pelbagai varian orientasi keagamaan. ${ }^{12}$

Bagaimana respon Muslim terhadap modernitas, sebagaimana dicatat oleh John Obert Voll, secara sederhana bisa diklasifikasikan menjadi dua arus besar utama yakni aliran revivalisme atau fundamentalisme di satu sisi dan aliran modernisme di sisi yang lain. Yang pertama berarti aliran yang berpegang teguh pada fundamen agama dalam hubungannya dengan modernitas melalui penafsiran terhadap kitab suci secara rigid dan literal. Sementara itu, kelompok kedua adalah kelompok keagamaan yang melakukan penafsiran terhadap doktrin agama untuk menyesuaikannya dengan perkembangan pemikiran modern. Mereka bermaksud mengintegrasikan Islam dengan nilai-nilai dan gagasan Barat modern. ${ }^{13}$ Dalam bahasa lain, yang pertama disebut oleh Akbar S. Ahmed sebagai kelompok yang intinya ingin melakukan konfrontasi terhadap modernitas sedangkan kelompok terakhir cenderung memilih jalan integrasi dan konsensus. ${ }^{14}$

Jadi, salah satu bentuk penyikapan Muslim terhadap modernitas adalah menolaknya secara tegas sambil kembali kepada idealisasi masa lampau dalam bentuknya yang rigid dan literal, yang oleh banyak akademisi gejala itu disebut dengan fundamentalisme. Kelompok fundamentalis melihat bahwa modernitas tidak akan mampu membawa dunia ini ke arah cahaya terang. Sebaliknya, justru mengantarkan ke arah obscurantisme, ${ }^{15}$ 
kebingungan, kekaburan, kehampaan, kekacauan, dan krisis dunia. Oleh karena itu, peneliti Islam seperti Bruce Lawrence misalnya juga melihat kelompok fundamentalis seperti Ikhwanul Muslimin di Mesir sebagai gerakan revolusi Islam menentang elit-elit sekular sekaligus revolusi terhadap modernitas di negara tersebut.

Pandangan tersebut diperkuat oleh Riaz Hassan dalam sebuah riset kuantitafnya bahwa fundamentalisme merupakan gerakan sadar diri sebagian masyarakat Muslim untuk melawan modernitas. ${ }^{16}$ Seperti halnya John L. Esposito yang menilai gejala fundamentalisme agama mewakili suatu pandangan bahwa sistem sosial, politik, ekonomi yang ada telah gagal; suatu kekecewaan dan seringkali berubah menjadi penolakan terhadap Barat; Karen Amstrong juga menyebut bahwa fundamentalisme merupakan ekspresi kekecewaan terhadap modernisasi yang terlalu jauh tidak bisa memenuhi janjinya serta melenyapkan agama. ${ }^{17}$ Francis Fukuyama berpendapat bahwa gerakangerakan fundamentalisme Islam merupakan reaksi keras sebagian orang Muslim yang merasa terancam oleh modernisasi dengan segala kemungkinan konsekuensi lanjutannya, seperti sekularisasi dan sekularisme yang pada gilirannya akan menyingkirkan Islam dari pelbagai aspek kehidupan. ${ }^{18}$

Artikel ini secara khusus akan memotret dan membahas gerakan fundamentalise Islam dengan Khilafatul Muslimin sebagai kasusnya. Saya tertarik untuk membahas gerakan ini sebagai kasus dan meletakkannya dalam perbincangan "Agama dan Modernitas." Sebagaimana akan terlihat pada pembahasan di bawah, dengan memegang teguh keyakinan agamanya, gerakan Khilafatul Muslimin (selanjutnya disebut KM) sangat kuat menolak sistem pemerintahan demokrasi sekuler yang dianggapnya sistem taghut atau kafir. Mereka juga menjadi komunitas yang tertutup, mengisolasi diri masyarakat melalui cara berpakaian dan gaya hidup sehari-hari. Dengan dalih agama, perempuan-perempuan mereka dilarang beraktivitas di ranah publik. Hak-hak politiknya diredam. Dengan demikian, kelompok ini meletakkan Islam vis a vis dengan modernitas atau bisa diklasifikasikan ke dalam kelompok fundamentalis Islam. Betapapun demikian, penyebutan fundamentalisme dan modernisme hanya digunakan sebagai cara pandang untuk membantu menjelaskan sebuah gejala sosial, dan bukan sebagai pelabelan.

\section{PROYEK MERCU SUAR ITU BERNAMA KHILAFATUL MUSLIMIN: TAPAK TILAS}

"Sistem kekhilafahan atau kepemimpinan Islam adalah sistem yang wajib disempurnakan keberadaannya di muka bumi. Sistem ini telah dicontohkan oleh para khalifah alrasyidun, sebagai kelanjutan kepemimpinan Nabi dalam mewujudkan kesejahteraan umat manusia lahir dan batin. Kekhilafahan tidak boleh absen dalam kehidupan umat Muslim, karena hanya melalui instrumen itulah umat dapat disatukan dalam satu jamaah. Oleh karena itu, jika kekhilafahan itu, karena berbagai alasan, tidak ada maka wajib hukumnya bagi umat Islam secara berkelompok maupun perorangan untuk mengumumkan dirinya sebagai amirul mukminin atau khalifah sedunia, untuk kemudian berupaya menyempurnakan segala persyaratannya."

Kutipan di atas adalah pernyataan Abdul Qadir Baraja, khalifah, yang disampaikannya 
kepada saya, yang sekaligus menggambarkan cita-cita atau proyek besarnya untuk mendirikan kekhalifahan Islam sejagad beberapa tahun lalu. Sebuah ikhtiar untuk kembali kepada peradaban Islam yang dulu sembari menolak segala gagasan ketatanegaraan Barat modern. Dan bermula dari gagasan itulah, proyek itu direalisasikan.

Di Bandar Lampung, 14 tahun yang lalu, gerakan ini dicetuskan. Tepatnya pada hari Jum'at, 13 Rabiul Awal $1418 \mathrm{H}$ atau 18 Juli 1997. Mengambil nama Khilafatul Muslimin atau Kekhilafahan Kaum Muslimin (selanjutnya ditulis KM), gerakan ini dipimpin oleh Abdul Qadir Baraja-teman Abu Bakar Ba'asyir. Komunitas atau jamaah gerakan tersebut memanggilnya dengan sebutan "Khalifah" atau amir dan membaiatnya sebagai pemimpin sah atas umat Islam seluruh dunia.

Tanpa ada batasan waktu, sejauh ini KM menjadikan Bandar Lampung sebagai ibu kota kekhalifahan Islam untuk sementara, dan tentu saja bisa dirubah. Namun sampai kapan, tidak ada perencanaan sama sekali. Yang jelas, penetapan kedudukan itu bersifat temporer dengan memperhatikan tempat tinggal sang khalifah saat ini yang menetap Bandar Lampung. Jika dimungkinkan, keputusan perubahan selanjutnya akan ditentukan sesuai dengan kesepakatan dari para perwakilan umat Muslim sedunia.

Mengikuti jejak Rasulullah Muhammad, KM membangun sebuah masjid sederhana 2 lantai dan menggunakannya sebagai sentral pemerintahan dan aktivitasnya. Pada lantai pertama adalah tempat menjalankan ibadah shalat, mengadakan taklim dan sebagainya. Sedangkan lantai kedua, adalah pusat aktivitas pemerintahan seperti rapat, menerima laporan, konsultasi dan sebagainya. Konon, ketika dalam proses pembangunanya, sang khalifah selalu turun ikut bekerja dan paling royal dalam menyedekahkan hartanya untuk kepentingan itu.

Ketika mengunjungi kantor pemerintahan KM saya bertemu dengan Akh. Rohim. Dia adalah pemuda asal Pringsewu, Lampung. Dibandingkan dengan mayoritas anggota KM lainnya, ia tergolong yang berpendidikan formal baik. Ia berhasil menamatkan pendidikan tingginya di sebuah Perguruan Tinggi Negeri Islam di Yogyakarta hingga memperoleh gelar master (S2). Dirinya menjelaskan bahwa secara teologis, berdirinya khilafattul Muslimin tidak terlepas dari pemahaman terhadap ayat al-Qur'an surat an-Nisa' ayat 49 yang artinya: "Hai orangorang yang beriman, taatilah kepada Allah dan taatilah RasulNya dan ulil amri di antara kamu." Bagi KM, kata ulil amri tidak bisa dimaknai dengan pemimpin/pemerintah suatu negara biasa pada umumnya. Ulil amri hanya benar bila dimaknai sebagai suatu pemerintahan Islam yang memerintah masyarakatnya berdasarkan ketentuan syariat atau hukum Islam dan berjalan di atas sitem Islami yakni kekhalifahan. ${ }^{19}$ Ulil amri juga harus secara aktif membimbing, mengajak dan mengarahkan masyarakatnya dalam ketaatan kepada Tuhan. ${ }^{20}$

Menurutnya, pada zaman dahulu, ulil amrinya adalah Rasulullah SAW secara langsung. Ulil amri setelah wafatnya Rasulullah adalah khalifah atau amirul mukminin atau imam umat Islam sedunia. ${ }^{21}$ Tak hanya itu, bagi KM, ketaatan umat Islam terhadap khalifah atau amirul mukminin adalah suatu kewajiban bagi setiap muslimin ataupun muslimah dan akan dipertanggungjawabkan di hadapan Allah 
kelak. Lebih lanjut, ketaatan terhadap ulim amri merupakan perintah untuk mendirikan khilafah Islamiyah sebagai satu satunya wadah bagi persatuan umat Muslim seluruh dunia berdasarkan ajaran agama. Dalam optik mereka, hanya lewat cara itulah akan syariat Islam bisa dilaksanakan, masyarakat Islami yang dicita-citakan bisa terwujud, serta umat Islam akan memiliki kebebasan dan kemerdekaan untuk menjalankan peribadatannya sesuai dengan keyakinan agamanya masing-masing. Baraja memberikan contoh ilustrasi menarik soal ini:

Di Mesir ada Universitas al Azhar yang umurnya lebih dari 1000 tahun. Alumninya sudah menyebar dimana-mana. Berapa banyak penghafal al-Qur'an yang dihasilkannya. Belum lagi para pakar tafsir al-Qur'an dan ahli hadits. Tapi, orang yang ingin melaksanakan syariat Islam di Mesir malah dipotong lehernya, dibunuh dan digantung. Itulah akibat tidak dijalankannya sistem khilafah yang berbasis Islam. Bagaimana pertanggung jawabannya nanti di akhirat? ${ }^{22}$

Untuk itu, kekhalifahan adalah sistem pemerintahan yang harus diusahakan, diperjuangkan oleh seluruh umat Islam karena. Kekhalifahan harus dirintis, dan generasi selanjutnya berkewajiban menyempurkannya. Ia merupakan prasyarat kejayaan Islam beserta kaum Muslim.

Mereka juga memahawi bahwa kunci kejayaan muslim masa dulu tercapai lantaran keberhasilannya dalam mempersatukan dan mempertahankan keutuhan umat berada di bawah satu kepemimpinan, yang disebut sebagai khilafah. Khilafah ini, secara organisasional dan politik, terbentuk karena adanya baiat berupa sam'an wa tha'atan (mendengar dan taat) dari rakyat kepada ulil amri atau pemimpin. Itulah yang disebut dengan baiat. ${ }^{23}$ Bunyi baiat warga kepada khalifah, yang diterakan dalam halaman belakang identitas kewarganegaraan KM adalah sebagai berikut:

a) Demi Allah sesungguhnya saya berbaiat kepada Allah dipersaksikan oleh amirul mukminin dengan ikhlas karena Allah taala;

b) Sesungguhnya saya tidak akan menyekutukan Allah dengan sesuatu;

c) Saya tidak akan mencuri, tidak akan berzina, tidak akan berbohong, dan tidak akan bermaksiat kepada Allah;

d) Saya menyatakan siap untuk mendengar dan taat kepada perintah Allah, Rasul dan ulil amri;

e) Saya siap menggunakan segala daya dan upaya dan apa-apa yang ada pada diri saya untuk meninggikan agama Allah;

f) Jika suatu saat nanti saya dengan sengaja menyalahi baiat ini, maka saya bersedia menerima hukuman seadil-adilnya berdasarkan hukum Allah. Dengan harapan Allah tetap menerima baiat saya dan Allah memudahkan saya dalam menjalankan kewajiban, mengampuni saya, dan meridai saya. Amin. Allahu akbar. Allahu akbar. Allahu akbar.

Tanpa ada baiat, maka persatuan umat tidak akan bisa dibentuk. Pengertian baiat seperti ini tentu saja berbeda dengan konsep baiat yang dipahami Fathi Osman yang menyamakannya dengan konsep kontrak sosial ala John Locke. Osman melihat konsep baiat sebagai komitmen penguasa untuk melayani rakyat sebaik mungkin, dan bukan sebaliknya permintaan kesetiaan oleh penguasa kepada rakyatnya. ${ }^{24}$ 
Hanya saja, sebagai catatan, sebagaimana dikemukakan oleh Ali, salah seorang pimpinan KM untuk wilayah Surabaya, bahwasanya baiat ini dibutuhkan manakala umat Islam yang bernaung di bawah khilafah ini masih sedikit. Ketika jumlahnya sudah banyak dan menyebar ke berbagai belahan dunia, maka baiat tidak lagi diperlukan. Sebab, hal itu secara teknis sulit dilakukan. Baiat dengan kata lain adalah penanda mana yang muslim sejati dan mana yang merupakan muslim munafik. ${ }^{25}$ Sebaliknya, kemunduran dan kehancuran Islam saat ini menurut Muslim sekarang tidak mampu mempertahankan kekhilafahan Islam. Akibatnya, umat Islam terpecah-pecah menjadi banyak golongan. Naifnya lagi, masing-masing golongan saling membanggakan diri dan masuk dalam fanatisme golongan. Padahal, berkelompokkelompok merupakan sebagian dari tandatanda orang kemusrikan. ${ }^{26}$

KM memahami bahwa khilafah Islamiyah itu berdiri sejak Nabi, kemudian khalifah empat hingga kekhalifahan Turki Usmani. Sayangnya, ketika saya tanyakan apakah Dinasti Abbasiyah dan Umayyah merupakan bagian dari kekhalifahan umat Islam yang sah, tidak didapatkan keterangan yang jelas. KM juga tidak menjelaskan bagaimana hukum perampasan kekhalifahan dari tangan Ali bin Abi Talib kepada monarki Umayyah. Bagi KM, kekhalifahan terakhir adalah Turki Usmani, yang lantas hancur karenanya adanya penghianatan dari Kemal Ataturk yang berkonspirasi dengan Inggris dan Yahudi. .

Setelah kehancuran itu sebenarnya sudah banyak dilakukan upaya oleh kaum Muslimin seluruh dunia. Tapi lagi-lagi, dalam pandangan Khalifah Baraja, hanya menghasilkan kongres dan kongres lagi. Kekhalifahan umat Islam tidak pernah benarbenar terwujud. Di Kairo, pernah diadakan kongres kekhaifahan Islam pada tahun 1926. Pada tahun yang sama Raja Ibnu Saud juga memprakarsai kongres Muslim sedunia di Makkah. Pada tahun 1931 juga diadakan kongres umat Islam sedunia di Masjidil Aqsha, Yerusalem. Konferensi Islam Internasional juga diadakan kedua kalinya di Karachi, Pakistan pada tahun 1949, selanjutnya yang ketiga diadakan lagi di Mekah pada tahun 1951 menyusul kemudian tahun 1964. Pada tahun 1974, diadakan Konferensi Tingkat Tinggi negara-negara Islam di Lahore. Dalam kesempatan tersebut presiden dari berbagai Negara di Timur Tengah mengusulkan agar Raja Faisal dari Arab Saudi menjadi amirul mukminin, tetapi dia tidak bersedia. ${ }^{27}$

Dalam konteks Indonesia sendiri, menurut Sang Khalifah Baraja, telah ada HOS. Cokroaminoto yang maju dengan gagasan pan-Islamismenya. Tapi juga gagal. Gagasan tersebut dilanjutkan oleh Kartosuwiryo dengan mendirikan NII pada tanggal 12 syawal $1368 \mathrm{H}$ atau bertepatan dengan 7 Agustus 1949. Usaha ini juga gagal, karena ditempatkan oleh penguasa sebagai pemberontak.

Hizbut Tahrir (selanjutnya ditulis HTI), tahun 2000, mengadakan konferensi khilafah pertama yang dihadiri oleh 5000 orang. Perkembangan secara signifikan amat terasa karena pada tahun 2007, HTI kembali menggelar acara serupa dan mampu mengumpulkan massa sebanyak 100.000 orang Muslim. Namun, Sang Khalifah justru mengkritik kongres tersebut karena pertama, terdapat paradoks, dimana kongres khilafah minus khalifah. Jadi seperti kongres guru, 
namun yang datang justru tukang jahit. Kedua, itu hanya menghasilan rekomendasirekomendasi advokasi pembentukan kekhalifahan Islam. Seharusnya, kongres itu menghasilkan kekhalifahan yang riil. ${ }^{28}$

Karena itu, meskipun pada tahun 1997 masih berada dalam penjara karena kasus pengeboman Borobudur, Baraja memaklumatkan berdirinya Khilafatul Muslimin sebagai bentuk kekhalifahan Islam yang benar-benar nyata. Konsep ini kemudian ditawar-tawarkan kepada orang yang pantas seperti Abu Bakar Ba'asyir selama kurang lebih tiga tahun. Sayangnya, tidak ada yang mau menerima amanah menjadi kahlifah atau amir. Ketika ada Kongres Mujahidin pertama di Yogjakarta pada tahun 2000, ${ }^{29}$ dia juga mensosialisasikan gagasannya. Rupanya tidak mendapatkan tanggapan yang berarti di kalangan peserta kongres. Di tengah-tengah keterbatasan itu, akhirnya dirinya dilantik menjadi khalifah bagi umat Muslim sedunia.

Karena itu, meskipun pada tahun 1997 masih berada dalam penjara karena kasus usaha pemboman Borobudur pada tahun 1977, Baraja memaklumatkan berdirinya Khilafatul Muslimin sebagai bentuk kekhalifahan Islam yang benar-benar nyata. Konsep ini kemudian ditawar-tawarkan kepada orang yang pantas seperti Abu Bakar Ba'asyir dll selama kurang lebih tiga tahun. Sayangnya, tidak ada yang mau menerima amanah menjadi kahlifah/amir. Ketika ada Kongres Mujahidin pertama di Yogjakarta pada tahun 2000, ${ }^{30}$ dia juga mensosialisasikan gagasannya. Rupanya tidak mendapatkan tanggapan yang berarti di kalangan peserta kongres. Ditengah-tengah keterbatasan itu, akhirnya dirinya dilantik menjadi khalifah bagi umat Muslim sedunia.

\section{DARI TOTALITAS ISLAM KE LITERALISME PEMAHAMAN}

Pada bagian ini saya akan menyuguhkan potret totalitas dan kesungguhan Abdul Qadir Baraja terhadap keyakinannya. Dibandingkan dengan pemimpin-pemimpin gerakan fundamentalisme Islam lainnya, pemimpin yang satu ini tidak cukup popular di media masa dan banyak penelitian lain. ${ }^{31}$ Ini terlihat dari sedikitnya liputan baik secara akademis maupun media. Bandingkan dengan Abu Bakar Ba'asyir, Abu Jibril, Ja'far Umar Thalib dan Habib Rizieq Shihab yang mendapatkan perhatian luas dari media massa.

Khalifah Baraja adalah lelaki tua yang shalih dan sederhana. Usianya kini sekitar 68 tahun. Kesederhanannya itu antara lain terlihat dari rumahnya yang sangat kecil. Di ruang tamunya yang hanya seluas sekitar $3 \times 4$ $\mathrm{m}$ dan terdapat televisi kuno dan karpet terbuat dari pelepah pohon pisang. Tak ada lagi perabotan lainnya. Meskipun berpangkat sebagai khalifah atau amir umat Muslim sedunia, dia tidak memiliki petugas keamanan yang berfungsi sebagai pengawal. Bagi dia, salah satu manifestasi Islam adalah kepasrahan total kepada Allah dalam segala urusan hidup dan mati. Tidak ada benda/ mahkluk yang patut ditakuti selain Allah. Karena itulah meskipun dirinya dianggap sebagai pemberontak oleh Pemerintah Republik Indonesia, dirinya merasa tidak perlu takut dengan polisi, intelijen dan tentara sehingga memerlukan pengawal seperti tokoh-tokoh gerakan Islam lainnya. Keberaniannya tumbuh sejalan dengan pengalamannya dalam usaha menegakkan Islam. Dia pernah bercerita bahwa sewaktu masih muda, dirinya aktif dalam gerakan NII. Karena itulah, dia sudah kebal dari intimidasi 
dan kejaran tentara dan intelijen. Bahkan, meskipun salah satu anaknya-menurut pengakuannya-mati ditembak tentara, dirinya tidak sedikitpun gentar dan mundur dari jalan yang ditempuhnya.

Ada kisah Khalifah Baraja sewaktu masih aktif di NII yang popular di kalangan anggota KM. Suatu ketika, khalifah dan satu temannya dalam pelarian di hutan. Mereka membangun sebuh gubuk. Pada tengah malam, syahdan gubuk itu sudah terkepung tentara, namun ia dan temannya masih bisa lari menyelamatkan diri dengan mengambil arah yang berbeda. Lama kemudian, temannya itu datang ke rumahnya dan menceritakan bahwa itu terkena tembakan di punggung saat berusaha kabur. Tapi ia tetap dapat berlari sampai di akhir tenaganya, dan sejurus kemudian ia jatuh dalam keadaan tak sadarkan diri. Saat terbangun, ia mendapati bahwa dirinya sudah berada di rumah. Setelah sembuh itulah, ia mengadukan peristiwa yang dihadapinya kepada Baraja. Dari pengalaman itulah, keteguhan hatinya terbentuk dan ia semakin yakin bahwa kematian berada di tangan Tuhan, bukan tentara. Bedil tentara sekalipun, tak akan mampu mencabut nyawa seseorang, selama Tuhan masih berkehendak lain. Begitulah totalitasnya.

Jaya, seorang lelaki tua dari daerah Waydadi, Lampung dalam kesaksiannya meneguhnya kesan itu. Kepada penulis dia mengakui:

"Saya bergabung dengan Khilafatul Muslimin karena takjub dengan perjuangan ustaz

Baraja. Saya tidak tertarik bergabung dengan Hizbut Tahrir karena tidak ada keberanian semacam itu yang patut diteladani,"

Setali tiga uang dengan totalitasnya terhadap Islam yang dipahaminya, Baraja juga memahami teks-teks al-Qur'an secara tekstual dan literal. Ini tentunya tidak mengherankan. Sebab, dimanapun, kelompok fundamentalis senantiasa menafsirkan al-Quran secara literal. Al-Qur'an adalah a word of God and is to be taken literally, word for word. ${ }^{32}$ Saya akan ungkapkan contohnya. Baraja, umpamanya, melihat bahwa masyarakat Muslim di Indonesia hidup di bawah hukum yang kafir. Sebab, Pancasila dan UUD 945 serta KUHP yang menjadi turunanya, yang berlaku tidak memiliki pijakannya dalam Islam..$^{33}$ Pelbagai produk undang-undang dan hukum adalah sepenuhnya buatan manusia (man made). Baginya, hukum Islam seperti qishash, potong tangan dan sebagainya harus ditegakkan. Sebab itulah yang dijelaskan alQur'an. ${ }^{34}$ Jika pemerintah tidak menegakkan hukum itu berarti tidak mendukung pelaksanaan syariat Islam dan demikian kafir. Dalam sebuah acara pengkaderan para dai KM di Sumbawa, Baraja mengatakan:

"Di dunia ini hanya ada dua golongan orang yakni orang yang beriman dan orang yang kafir. Di tengahnya sebetulnya ada orang yang katakanlah moderat. Istilah lainnya adalah munafik. Orang munafik adalah orang yang mengaku Islam tapi tidak mau melaksanakan syariat Islam secara kaffah, ia mendukung sistem pemerintahan taghut. Orang munafik ini pada akhirnya akan lebih condong kepada kekafiran."

"Penerimaan terhadap Islam memiliki beberapa konsekuensi sekaligus. Mengimani Islam sebagai agama haruslah berarti melaksanakan ajaran agama secara kaffah. Sebab Islam adalah agama yang sempurna, agama yang syumul. Islam tidak hanya 
mengatur persoalan ibadah, tetapi juga menyangkut seluruh aspek kehidupan manusia. Jangankan masalah pemerintahan yang merupakan payung utama penegakan agama, memotong kuku pun ada aturannya. Dan ke-kaffah-an itu tidak hanya sebatas pada masalah substansi, melainkan juga harus pula mencakup dimensi institusi dan konstitusi. Berislam tidak hanya menjalankan kewajiban shalat, zakat, tetapi sistem kenegaraan dan undang-undangnya pun harus berdasarkan pada syariat."

Konsekuensi dari keyakinan bahwa kekhilafahan sebagai sistem pemerintahan Islam yang benar (haq) berarti bahwa segala bentuk sistem pemerintahan dan bernegara seperti demokrasi, komunisme, nasionalisme adalah merupakan sistem yang batil atau yang dalam bahasa Al-Qur'an disebut sebagai sistem taghut. Baraja juga menambahkan bahwa Islam tidak akan mungkin bisa hidup tegak secara sempurna di dalam sebuah sistem yang tidak Islami seperti itu. Oleh karena itu, implikasi selanjutnya, seluruh perjuangan partai-partai Islam melalui arena demokrasi menjadi amal usaha yang sia-sia belaka. Sebab, bukannya meninggikan hukum Islam, melainkan secara langsung justru mendukung tegaknya sistem taghut tersebut. Padahal yang diinginkan Islam adalah hilangnya sistem taghut itu.

Lebih jauh lagi, Endi, seorang yang bertugas di kantor pemerintahan KM menjelaskan:

"Seseorang yang menghabiskan seluruh hidupnya untuk membicarakan Islam, jihad, haji, salat, dakwah, dan al-Qur'an tetapi jika tidak menolak taghut beserta sistemnya; demokrasi, sosialisme, kapitalisme dan sebagaianya, maka tidak ada gunanya ke-
Islamannya. Hal ini karena menolak taghut adalah syarat pertama seorang muslim yang terwujudkan dalam kalimat "Tiada Tuhan selain Allah." 35

Pendapatnya ini tentu saja berbeda dengan sejumlah kalangan yang menilai bahwa Pancasila dan UUD 1945 dan dalam perundang-undangan pelaksanaannya pada dasarnya berjiwakan, bernafaskan Islam. Ahmad Sukardja misalnya secara tegas mendedahkan kepada kita bahwa meskipun kata Islam, al-Qur'an dan Hadits tidak tercantum secara eksplisit di dalam konstitusi negara Indonesia, namun sifat keIslamannya jelas sangat tampak. Isi UUD 1945 sesuai dan tidak ada yang bertentangan secara hakiki dengan Islam. Ia menempatkan manusia dalam kedudukan yang sama di hadapan hukum dan pemerintahan, tidak memberatkan masyarakat, menegakkan keadilan, serta bertujuan menciptakan kemaslahatan bersama serta menjauhkannya dari kemudharatan. ${ }^{36}$ UU yang mengatur tentang perkawinan, ibadah haji, kewarisan, wakaf, Departemen Agama, Peradilan Agama serta adanya MUI menunjukkan tesis itu. Keseluruhannya selaras dengan Islam. Senafas dengan Sukardja, Faisal Ismail juga menegaskan bahwa besarnya dukungan Muslim di Indonesia dan penerimaanya terhadap bentuk negara Indonesia mengisyaratkan bahwa Islam dan negara Pancasila tidak saling bertentangan. ${ }^{37}$

\section{MENYUARAKAN KEMBALI KHILAFAH, MENANTANG DEMOKRASI}

Persoalan mengenai bentuk negara dan pemerintahan yang ideal bagi masyarakat Muslim dewasa ini masih menjadi perdebatan yang belum selesai-dan 
tampaknya tidak akan pernah selesai. Konsep negara modern, yang ditandai dengan sistem demokrasi di dalamnya-meski boleh jadi beda format dan derajat kedalamannya, telah dan terus diterapkan oleh negara-negara berpenduduk Muslim. Di waktu yang sama, tak sedikit pula gerakangerakan fundamentalis yang menyerukan pentingnya kekhalifahan dan negara Islammeski suara itu nyaris menjadi impian yang sampai kini tak pernah terwujud.

Munawir Sjadzali dengan sangat cermat menyebut bahwa dalam pandangan masyarakat Muslim setidaknya terdapat tiga konsep tentang negara Islam. Pendapat pertama menyatakan, bahwa Islam adalah agama sempurna dan lengkap dengan pengaturan bagi segala aspek kehidupan manusia, termasuk kehidupan politik dan negara. Umat Islam harus merujuk kepada sistem ketatanegaraan Islam sebagaimana dicontohkan Muhammad dan khalifah yang empat, sekaligus membuang jauh-jauh konsepsi serta pemikiran Barat mengenai itu. Pendapat kedua, Islam adalah suatu agama an sich yang tidak ada kaitannya dengan persoalan politik dan negara. Muhammad adalah utusan Allah untuk menyebarluaskan ajaran Islam dan tidak bertugas untuk mendirikan suatu negara. Menengahi dua kubu di atas, pendapat ketiga menyatakan bahwa meskipun Islam adalah agama yang sempurna dan mengatur keseluruhan hal. Namun, sifatnya secara umum dan pada pokok-pokoknya saja. Islam tidak memiliki aturan tentang ketatanegaraan secara lengkap, namun hanya memberikan petunjuk-petunjuk umum serta etika. ${ }^{38}$

Jika dimasukkan dalam pengelompokan di atas, maka gerakan Khilafatul Muslimin ini jelas masuk dalam kategori pertama sebagaimana tercermin dalam kutipan Khalifah berikut ini:

"Al-Khilafah atau imamah merupakan prasyarat mutlak (conditio sine qua non) bagi tegaknya Islam di muka bumi. Al-Khilafah merupakan induk dari lembaga-lembaga lain di dalam masyarakat, yang tanpanya maka lembaga-lembaga lain akan kehilangan dasar pijakannya. Karena, secara internal, khilafah merupakan justifikasi bagi penegakan syari'ah. Sedangkan secara eksternal, khilafah merupakan pengejawantahan kekuasaan untuk kesejahteraan kekuasaan untuk kesejahteraan dan kedamaian umat guna mewujudkan tata dunia baru yang berorientasi pada keadilan dan kedamaian di muka bumi."

Salah satu problem mendasar yang terdapat dalam demokrasi adalah pengakuannya terhadap kedaulatan di tangan rakyat. Ini adalah sesuatu yang secara jelas berhadapan dengan Islam. Dalam Islam, kedaulatan (souverenitas) ada di tangan Tuhan, bukan manusia. Al-Quran menunjukkan bahwa otoritas serta kedaulatan tertinggi ada di tangan Allah. ${ }^{39}$ Yang bermakna pula bahwa Tuhanlah yang berhak memberikan hukum bagi manusia. Manusia tidak memiliki hak untuk menyususn hukum

Dzulkifli, mantan amir wilayah Nusa Tenggara yang kini menjadi amir 'Daulah Indonesia' menyatakan bahwa konsep khilafah Islamiyah tidaklah sama dengan konsep negara Islam. Sebab, negara Islam dibatasi oleh geografis tertentu, sementara kekhalifahan berlaku secara universal mendunia tanpa sekat-sekat geografis, budaya, suku dan sebagainya. Selain itu, 
belajar dari strategi dakwah Rasulullah, dakwah Islam tidaklah dimulai dari negara, melainkan dari orang per- orang.

Kepemimpinan itu diawali dengan apa yang sering disebut sebagai takliful qulub atau merebut dan menyatuan hati masyarakat untuk menerima Islam, bukan dengan takliful quwwah atau merebut kekuasaan. Dari situ kemudian Rasulullah lantas melakukan baiat atau sumpah setia orang-orang yang sudah beriman, dan mewajibkan atas mereka ketaatan terhadap ajaran Islam. Dari situlah komunitas serta kesatuan umat Islam akan dengan sendirinya terbentuk. Sebuah kesatuan umat yang tidak dibatasi oleh territorial geografis, negara, bangsa, ataupun ras tertentu. Akan tetapi, komunitas yang melampaui itu semua berdasarkan kesamaan, kesatuan iman yang membentuk umat. ${ }^{40}$

Dalam konstitusinya, dijelaskan bahwa KM ini berasaskan Islam dan kemerdekaan, bertujuan memakmurkan bumi dan menyejahterakan umat melalui pelaksanaan ajaran Allah dan Rasulnya bersama kebebasan penerapan ajaran semua agama sebagai prinsip dasar jamaah tanpa memperkenankan seorang warganya membuat aturan, ketentuan, norma-norma yang bertentangan dengan ajaran agamanya sendiri. Selain itu, Jamaah KM ini akan menyelesaikan suatu perkara atau urusan yang menyangkut kepentingan umat melalui musyawarah kekhalifahan secara transparan, penuh keterbukaan dan kebebasan berlandaskan akhlaq al-karimah. KM juga akan senantiasa berusaha maksimal untuk mewujudkan kerja sama antar umat manusia sesuai ajaran demi keadilan dan kesejahteraan mereka serta kelestarian alam semesta atau rahmatan lil alamin.
Dalam hubungan internasionalnya dengan negara lain, KM pada prinsipnya cinta akan kedamaian dan tidak akan melancarkan permusuhan, apalagi peperangan terhadap golongan mana pun, kecuali hanya berkewajiban membela diri dari serangan kelompok atau golongan yang memeranginya. Dalam masalah

kewarganegaraan, KM memberikan identitas anggotanya dengan sebuah kartu identitas layaknya KTP dengan cara mendaftarkan diri. Kewarganegaraan dalam sistem KM dibagi menjadi dua: pertama, adalah Muslim atau Muslimah tanpa diskriminasi rasial, golongan, kebangsaan maupun jabatan dan berkewajiban menyerahkan infak dan zakatnya ke Baitul Mal KM. Kedua, adalah masyarakat non-Muslim yang mendambakan keadilan dan kesejahteraan umat serta bersedia patuh terhadap khalifah atau amirul mukminin sepanjang tidak bertentangan dengan agama yang diyakininya, dan rela menyerahkan sumbangan menurut kemampuannya ke Baitul Mal KM demi kesejahteraan bersama lahir batin.

Layaknya pemerintahan pada umumnya, mereka juga memiliki struktur yang menopang kekhilafahan mereka. Struktur pemerintahan tertinggi adalah Khalifah atau Amirul mukminin, yakni Abdul Qadir Baraja. Ia menetap di Lampung, sebagai pusat pemerintahan. Struktur di bawahnya terdapat Katib al-Khilafah (wakil atau sekretaris khalifah). Ia bertugas membantu menjalankan pemerintahan manakala khalifah tidak berada di pusat pemerintahan. Meski keduanya merupakan pelaksana tugas tertinggi dalam struktur pemerintahan, namun di atasnya terdapat sebuah dewan yang disebut mustasyar 
(penasehat), yang setara dengan wilayatul faqih di Iran. Merekalah yang berwenang memberi masukan, saran kepada khalifah terhadap masalah umat yang perlu dipecahkan.

Tepat di bawah khalifah adalah wazir (menteri) yang membantu khalifah dalam bidang-bidang yang telah ditentukan. Mereka diangkat oleh khalifah. Jumlah menteri merupakan hak mutlak khalifah dan disusun dengan mempertimbangkan kebutuhan masyarakat Muslim. Pada tahun 2008, misalnya, terdapat menteri pendidikan dan pengajaran yang dijabat Sobirin.

Menteri pendataan umat dan inventaris dijabat oleh Rafli. Menteri keuangan dipegang oleh Waluyo. Menteri perhubungan, Suryadi. Menteri Ekonomi dan Pemberdayaan Usaha, Abdurrahim. Menteri Pertahanan dan Keamanan adalah Irza. Sedangkan Menteri Olahraga dan Kesehatan adalah Jainuri.

Sekarang, sejumlah jabatan sudah berganti dan berubah. Menteri Pendataan Umat dan Inventaris (Wazir Tasjil Wat Taftisy) adalah Ghulam Siddiq telah melakukan ikhtiar pemutakhiran formulir pendataan warga yang memuat berbagai poin penting bagi database kewargaan ke depan. Menteri bidang dakwah dan pembinaan ummat adalah Aminuddin. Menteri Perhubungan (Wazir Muwashalatil Ijtima'iyyah) adalah Mukhliansyah. Tugasnya mengatur perjalanan Amir Daulah ke berbagai Wilayah di Pulau Jawa dan Sumatera. Menteri Bidang Ekonomi (Wizaaratul Iqtishodiyyah Wat Tadbiiril Kasbi) adalah Ammar. Tugasnya antara lain, membangun usaha mikro untuk membuka lapangan kerja baru dan pemanfaatan sumber daya alam yang ada di sekitar warga jamaah tinggal untuk dieksporasi dan dieksploitasi secara beradab dan tetap bersahabat dengan alam, seperti program usaha pengadaan Air Minum Isi Ulang dalam kemasan gelas, bagi warga jamaah di Pacet, Mojokerto yang dekat dengan sumber air bersih.

Menteri Kesehatan (Wazir Ash-Shihhah) adalah Muhammad Yusuf Abu Qoyyim. Programnya antara lain membangun sarana Kesehatan ( klinik atau gerai sehat) untuk warga KM dengan biaya relatif murah, bahkan grastis dengan tanggungan dana Baitul Maal; menerbitkan Bulletin Ash Shihhah; menyelenggarakan Pelatihan AtTibbun Nabawi di setiap wilayah; membangun jaringan antara klinik sehat yang sudah ada, yaitu Ibnu Qoyyim Medical Centre (IQMC) yang ada di Tambun, Bekasi; melayani konsultasi kesehatan bagi warga Khilafah melalaui SMS dan Telephon, dan mengupayakan program Imunisasi alami atau Islami bagi bayi-bayi warga Khilafah. ${ }^{41}$

Struktur pemerintahan KM terdiri atas beberapa bagian, berikut ini:

1. Khalifah atau amirul mukminin.

Khalifah menetap di Lampung, sebagai pusat pemerintahan. Pusat pemerintahan dapat dipindah-pindah.

2. Katib al-khilafah yang disebut juga wakil atau sekretaris Khilafah yang membantu tugas khalifah ketika tidak ada di pusat pemerintahan

3. Mustasyar adalah penasehat khalifah, yang memberikan masukan dan saran guna memberikan solusi atas permasalahan umat yang perlu dipecahkan bersama

4. Para wazir adalah para menteri yang membantu khalifah dalam bidang-bidang yang telah ditentukan. Jumlah menteri dibentuk dengan mendasarkan pada 
kebutuhan umat di lapangan. Sejauh ini baru ada beberapa menteri saja yakni menteri pendidikan dan pengajaran yang dijabat oleh Sobirin, menteri pendataan umat dan inventaris yang dijabat oleh Rafli, menteri keuangan dipegang oleh Waluyo, menteri perhubungan dijabat oleh Suryadi, menteri ekonomi dan pemberdayaan usaha oleh Abdurrahim, menteri pertahanan dan keamanan diamanatkan kepada Irza, serta menteri olahraga dan kesehatan yang dijabat oleh Jainuri.

5. Amir daulah adalah pemimpin atau wakil khalifah yang mengurusi umat dalam batas teritoria negara tertentu. Sejauh ini belum terdapat amir daulah, mengingat KM masih berkembang di Indonesia saja.

6. Amir wilayah adalah pemimpin yang mengurusi umatnya di tingkat provinsi

7. Amir ummul qura adalah pemimpin yang mengurusi umat di tingkat kabupaten atau kotamadya

8. Mas'ulul ummah adalah penanggung jawab umat di tingkat kabilah atau kelurahan. Jumlah mininum untuk dapat dibentuk kabilah ini adalah sebanyak tiga orang. Sebelum memenuhi batas minimal tersebut, maka mereka bergabung dengan kelurahan lain terdekat.

Dalam pandangan Baraja, kekhalifahan adalah anugerah Tuhan sebagai bukti cintanya kepada manusia. Dia menjelaskan:

"Islam adalah agama yang hak dan sempurna.

Kesempurnaannya mencakup segala hal.

Kalau ada orang yang bilang, Islam tidak mengatur masalah politik itu sebuah

kebohongan. Kesempurnaan agama ini adalah sebagian bukti cinta Allah kepada manusia.

Oleh karena itulah, dibekalkan syariat kepada manusia agar bisa menjalani kehidupan dengan selamat. Saat ini syariat telah lama menghilang dari kehidupan tanpa disadari. Umat Islam telah lama hidup dalam dunia tanpa syariat karena ketiadaan sistem yang mampu menjamin berjalannya syariat secara sempurna. Ketiadaan kekhalifahan bagi seluruh umat Islam adalah bencana terbesar. Sekarang ini banyak di antara umat Islam yang menginginkan hidup secara Islami, namun tidak mau merubah sistem kehidupan yang telah ada selama ini kepada sistem yang lebih sesuai dengan syariat agama. Akibatnya, orang Islam bagaikan hidup di dua alam.

Hatinya ingin beriman, namun merasa betah hidup di dalam sistem yang kafir. Hidup di dua alam itu, pada akhirnya, mengikis idealisme orang Islam sendiri, sehingga tanpa disa dari ia telah meninggalkan ajaran agama Islam. Sesuatu hal yang amat diharamkan."

Dengan posisi ini, maka jelas bahwa kekhlifahan bagi KM adalah sebuah keharusan, kewajiban. Mengikuti atau berIslam di bawah payung sistem selain kekhalifahan adalah suatu kekafiran. Pandangan ini jelas berbeda, misalnya dengan Husein Heikal. Bagi Heikal, tidak ada keraguan sama sekali bahwa Islam dan demokrasi adalah sinkron dalam semua hal yang esensial. Bahkan, lebih jauh, ia mengatakan bahwa setiap sistem yang yang tidak berdiri di atas prinsip-prinsip demokrasi adalah tidak sesuai dengan kaidah-kaidah utama yang diserukan oleh Islam. ${ }^{42}$

\section{KEDUDUKAN PEREMPUAN DALAM MASYARAKAT KM}

Akbar S. Ahmed dalam bukunya Living Islam menuliskan pandangannya bahwa semakin Islam ditegakkan semakin 
perempuan bisa maju. Begitu pula sebaliknya. Perempuan muslim, lanjut Ahmad, akan memiliki kepercayaan yang tinggi ketika Islam dalam keadaan aman; mereka menjadi tidak yakin dan tidak aman saat Islam dalam posisi defensif. Dimana peran Islam dominan, wanita memainkan peran hak mereka dalam masyarakat secara penuh dan tidak dihalangi. Dimana Islam dihancurkan, sebuah tirai akan menutupi rumah-rumah Muslim dan wanita-wanita akan disembunyikan. ${ }^{43}$ Kesimpulan Akbar S. Ahmed itu tentu tidak bisa menemukan konteks kebenarannya jika diletakkan dalam lokus KM. Sebab, dalam KM, semangat untuk menegakkan ajaran agama Islam justru dibarengi dengan pengurungan terhadap perempuan. Sekaligus membenarkan tesis Moaddel mengenai sikap tak ramah kelompok Muslim fundamentalis terhadap perempuan. ${ }^{44}$

Dalam kehidupan sehari-hari yang saya amati, kehidupan perempuan KM begitu terpisah dari kehidupan laki-laki. Sepanjang saya melakukan pengamatan dan wawancara, tak ada satu pun ikhwan KM yang membolehkan istrinya bekerja di luar, kecuali mengajar kelas perempuan, ke pasar dan sejenisnya. Ke pasar pun harus disertai seorang mahram. Meski tidak ada ketentuan baik secara implisit dan ekplisitnya dari al-Qur'an yang justru menjelaskan tentang prinsip kesejajaran dan kemitraan $^{45}$, ada ketentuan tegas dalam jamaah KM bahwa sementara laki-laki mengartikulasikan diri di ruang-ruang publik, perempuan memperoleh jatahnya di ruang privat, dalam keluarga (domestik). Secara legal dan politik, KM mengharamkan perempuan menjadi pemimpin. Ini ditegaskan dalam konstitusinya. Terkait dengan isu kepemimpinan, sejauh ini KM memberikan dua persyaratan penting bagi seseorang yang ingin ditetapkan sebagai seorang khalifah. Pertama, laki-laki. Menurut Baraja, pergantian kepemimpinan dalam Islam mensyaratkan seorang laki-laki yang harus menjadi atau khalifah, dan hal tersebut sudah menjadi ketetapan para ulama. Kedua, tidak harus orang keturunan kaum Quraish, sebagaimana banyak dipahami.

Menurut Baraja, masalah khilafah adalah masalah umat dan karena itu tidak ada suatu kelompok atau golongan manapun yang berhak memonopoli persoalan menjadi syarat kepala negara. Siapapun orangnya, arab ataupun bukan, bukanlah menjadi persoalan sepanjang ia sanggup memimpin dan mengurusi umat serta memiliki ketaqwaan kepada Allah. Terkait dengan adanya teks Hadits Nabi yang menyatakan pemimpin harus berasal dari kalangan suku Quraish, menurut Baraja, haruslah dipahami sebagaimana konteks waktu itu yang mana mereka dulu memang memiliki kualitas kepemimpinan yang lebih dari suku-suku lain waktu itu. ${ }^{46}$ Dari kasus ini, tampak bahwa mereka cederung tidak konsisten. Padahal, jika logika yang sama diterapkan untuk melihat masalah kepemimpinan, maka sebetulnya laki-laki maupun perempuan memiliki peluang yang sama.

Secara sosial dan budaya, para perempuan warga KM diwajibkan mengenakan burqa yang lebar, hanya menyisakan bagian mata dan umumnya berwarna hitam. Tubuh perempuan adalah aurat yang harus diselamatkan dan dilindungi dari lingkungan yang berbahagia. Mereka juga berupaya menjaga kemurnian Islam dengan itu. Berpakaian, dengan demikian, sebagaimana 
diungkapkan Bruce Lawrence, adalah perlambang atau simbol proses balik menuju identitas yang lebih Islami. Kepulangan kepada cara-cara berpakaian muslim dahulu ala Arab adalah salah satu cara untuk memeperoleh kembali makna Islam yang hilang. Seorang laki-laki mengenaikan baju gamis dan seorang perempuan memakai hijab. Keduanya berupaya memperoleh kembali makna dan identitas Islam. Pandangan semacam itu lantas dikristalkan bahwa itulah cara berpakaian satu-satunya yang benar menurut Islam, sementara gaya berpakaian masyarakat Muslim pada umumnya tidaklah bisa dinilai Islami. ${ }^{47}$

Ketika mengunjungi rumah-rumah anggota KM, saya mendapati bahwa para perempuan harus tetap di dalam rumah bagian belakang serta tidak diperkenankan ikut menemui tamu, kecuali anak perempuan yang masih di bawah umur. Ini berbeda dengan masyarakat Muslim kebanyakan. Dalam lingkungan pendidikan, kelas laki-laki juga dipisahkan dari kelas perempuan. Ini terlihat jelas dalam sekolah Taman Kanak dan Taman Pendidikan Qur'an yang mereka dirikan. Apa yang dilakukan oleh KM terhadap perempuan semakin mengkristalkan perlakuan kelompok fundamentalis yang menggunakan bahasa agama, yang bukannya untuk membebaskan, namun justru untuk menindas kaum perempuan..$^{48}$

\section{KESIMPULAN}

Terlahir sebagai respon terhadap perkembangan modernitas, KM muncul dengan seruan kembali kepada ajaran-ajaran agama yang murni. Dengan semangat keagamaan yang tinggi, mereka mengusung misi besar untuk menegakkan khilafah sebagai satu-satunya sistem pemerintahan Islami-melawan demokrasi, memahami kitab suci secara apa adanya dan mengatur kehidupan masyarakatnya berdasarkan cetak biru darinya seperti terlihat dalam pembagian peran lelaki dan perempuan. Perempuan dipinggirkan dari kehidupan publik, sehingga tidak memperoleh hak-haknya secara setara sebagaimana diyakni masyarakat modern. Singkatnya, tidak seperti Francis Fukuyama yang menyebut dunia telah berakhir dengan kemenangan demokrasi dan kapitalisme, ${ }^{49}$ bagi mereka dunia saat ini bergerak di jalan yang salah. Perlu dikoreksi. Supaya, ia berakhir di jalan yang benar; dipelukan tuntunan ilahi.

\section{CATATAN AKHIR}

1 Lihat dalam Anthony Giddens, Kapitalisme dan Teori Sosial Modern: Suatau Analisis Karya Tulis Marx, Durkheim dan Max Weber (Jakarta: UI Press, 1985), h. 252. Lihat juga Alan Aldridge, Religion in the Contemporary World (Cambridge: Polity, 2008), h. 70.

2 Pippa Norris dan Ronald Inglehart, Sekularisasi Ditinjau Kembali: Agama dan Politik di Dunia Dewasa Ini (Jakarta: Paramadia dan Alvabet, 2009)

3 Mark Juergensmeyer, Menentang Negara Sekuler: Kebangkitan Global Nasionalisme Religius (Bandung: Mizan, 1998).

4 Charles Davis, Religion and The Making Society: Essays in Social Theology (Cambridge: Cambridge University Press, 1994)

5 Gilles Kepel, Pembalasan Tuhan: Kebangkitan Agamaagama Samawi di Dunia Modern (Jakarta: Pustaka Hidayah, 1997), h. 10.

6 Michael Burleigh, Earthly Power: The Clash of Religion and Politics in Europe From the French Revolution to the Great War (Australia: Harper \& Collins, 2007)

7 Saya menggunakan kata Muslim ketimbang Islam lantaran membedakan Islam sebagai social blueprint yang sakral dengan bagaimana Muslim memahami, menterjemahkan Islam ke dalam realitas sosial yang dengan sendirinya masuk dalam wilayah profan. Penggunaan kata Muslim dengan demikian membatasi pada objek yang dibahas, dan bukan untuk menilai dan menggeneralisir Islam secara keseluruhan. Sebab, Islam itu satu sementara Muslim sangat banyak. Diskusi mengenai ini lihat antara lain 
Gabriele Marranci, The Anthropolgy of Islam (Cambridge: Berg, 2008), h. 31-52.

8 Lihat lebih lanjut dalam Dick van der Meij, Dinamika Kontemporer dalam Masyarakat Islam (Jakarta: INIS, 2003), h. 193-194.

9 Ernest Gellner misalnya berpendapat bahwa Islam merupakan agama yang paling sesuai dengan modernitas karena karakternya yang kosmopolit dan universal. Hanya saja, Muslim saat ini mengalami fluktuasi dan bandulnya mengayun mundur meninggalkan karakter asal sebagaimana diperlihatkan para Muslim generasi awal. Lihat Ernest Gellner, Muslim Society, (Cambridge: Cambridge University Press, 1981). Sejalan dengan Gellner, Mark Woodward juga menilai bahwa dibandingkan dengan Kristen, Islam merupakan agama yang paling terbuka terhadap modernitas. Tak ada satu pun dalam aspek teologi Islam yang bertentangan dengan modernitas. Lihat Mark R. Woodward, "Modernity and The Disenchantment of Life: A Muslim-Christian Contrast" dalam Johan Meuleman (ed.), Islam in the Era of Globalization: Muslim Attitude Towards Modernity and Identity (London: Routledge, 2005), h. 80-102.

10 Sayyid Outub, Petunjuk Jalan (Jakarta: Media Dakwah, 1987), cet. 3 .

11 Robert N. Bellah, Beyond Belief Menemukan Kembali Agama: Esai-esai tentang Agama di Dunia Modern (Jakarta: Paramadina, 2000)

12 M Bambang Pranowo, Islam Faktual: Antara Tradisi dan Relasi Kuasa (Yogyakarta: Adicita, 1998)

13 John Obert Voll, Islam: Continuity and Change in The Modern World (Colorado: Westview Press, 1982), h. 146. Lihat juga Yusril Ihza Mahendra, Modernisme dan Fundamentalisme dalam Politik Islam: Perbandingan Partai Masyumi (Indonesia) dan Partai Jama'at-i-Islami (Pakistan), (Jakarta: Paramadina, 1999). Lihat juga Harun Nasution dan Azyumardi Azra, Perkembangan Modern Dalam Islam (Jakarta: Yayasan Obor Indonesia, 1985).

14 Akbar S. Ahmed, Living Islam: Tamasya Budaya Menyusuri Samarkand hingga Stornoway (Jakarta: Mizan, 1997).

15 Gilles Kepel, Pembalasan Tuhan: Kebangkitan Agamaagama Samawi di Dunia Modern (Jakarta: Pustaka Hidayah, 1997)

16 Riaz Hassan, Keragaman Iman: Studi Komparatif Masyarakat Muslim (Jakarta: PPIM dan Rajawali Pers, 2006)

17 Karen Amstrong, Islam: A Short History Sepintas Sejarah Islam (Surabaya: Ikon Teralitera, 2004), h. 193-197.

18 Francis Fukuyama, Benturan Islam dan Modernisasi, Koran Tempo, 26. November (2001).

19 Wawancara dengan Akh. Rohim

20 Abdul Oadir Baraja, Gambaran Global Pemerintahan Islam, (Surabaya: RAP, 2001), h. 23.
21 Bandingkan dengan Abul A'la al-Maududi, Khalifah dan Kerajaan, (Bandung: Mizan, 1984), h. 73.

22 Wawancara dengan Abdul Oadir Baraja

23 Abdul Oadir Baraja, Gambaran Global Pemerintahan, h. 92.

24 Lihat lebih lanjut dalam Fathi Osman, "Bay'ah al-Imam: Kesepakatan Pengangkatan Kepala Negara" dalam Mumtaz Ahmad, (ed.), Masalah-masalah Teori Politik Islam, (Bandung: Mizan, 1996), h. 113, 75.

25 Wawancara dengan Ali

26 Lihat OS. Ar-Rum : 31-32 yang berarti "Janganlah kalian termasuk orang-orang yang musyrik yaitu orangorang yang memecah belah agama mereka menjadi beberapa golongan, tiap-tiap golongan merasa bangga dengan apa yang ada pada golongannya itu."

27 Wawancara dengan Abdul Oadir Baraja

28 Wawancara dengan Abdul Oadir Baraja

29 Tentang kongres ini lihat Irfan S Awwas, Risalah Kongres Mujahidin I Dan Penegakan Syariat Islam (Yogyakarta: Wihdah Press, 2001)

30 Tentang kongres ini lihat Irfan S Awwas, Risalah Kongres Mujahidin I Dan Penegakan Syariat Islam (Yogyakarta: Wihdah Press, 2001).

31 Dalam banyak penelitiannya terhadap gerakan radikal di Indonesia, misalnya, PPIM tidak memberikan perhatian terhadap gerakan ini. Lihat misalnya, Jamhari dan Jajang Jahroni, (ed.), Gerakan Salafi Radikal di Indonesia (Jakarta: Rajawali Press, 2004)

32 Peter Herriot, Religious Fundamentalism: Global, Lokal, Personal (London: Routledge, 2009), h. 59.

33 Bandingkan dengan pendapat Ahmad Syafi'i Maarif, bekas ketua umum PP Muhammadiyah, yang menjelaskan bahwa antara Islam dan kelndonesiaan sesungguhnya berada dalam satu tarikan nafas. Susunan kimiawi antara Islam dan keindonesiaan bertemu dalam anyaman yang padu, saling mengisi dan memperkaya. Lihat lebih lanjut dalam Ahmad Syafii Maarif, Islam dalam Bingkai Keindonesiaan dan Kemanusiaan: Sebuah Refleksi Sejarah (Bandung: Mizan, 2009), h. 16.

34 Baraja, Gambaran Global Pemerintahan, h. 56.

35 Wawancara dengan Endi. Lihat juga laporan Utama, Mufti Taghut adalah Taghut, Majalah al Khilafah, edisi 5. th. 2. Shafar (1429 H)

36 Ahmad Sukardja, Piagam Madinah dan UUD 1945: Kajian Perbandingan Tentang Dasar Hidup Bersama Dalam Masyarakat Majemuk ( Jakarta: UI Press, 1995), h. 176

37 Faisal Ismail, Ideologi Hegemoni dan Otoritas Agama: Wacana Ketegangan Kreatif Islam dan Pancasila (Yogyakarta: Tiara Wacana, 1999), h. 302

38 Munawir Sjadzali, Islam dan Tata Negara: Ajaran, Sejarah dan Pemikiran (Jakarta: UI Press, 1990), h. 1-2

39 OS. 12: 40, OS. 3: 154 dan 79; OS. 16:116

40 Wawancara dengan Dzulkifli di Nusa Tenggara Barat 
41 Lihat dalam http://www.khilafatulmuslimin.com/blog/ perkembangan-daulah-khilafatul-muslimin. Diakses tanggal 7 Maret 2012

42 Muhammad Husein Heikal, Pemerintahan Islam (Jakarta: Pustaka Firdaus, 1993), h. 87-88.

43 Akbar S. Ahmed, Living Islam, h. 224

44 Lihat lebih lanjut dalam Mansoor Moaddel, "Religion and Women: Islamic Modernism versus Fundamentalism," Journal for the Scientific Study of Religion. Vol. 37. No. 1. (1998) h. 108-130.

45 Lihat M. Quraish Shihab, "Kesetaraan Jender Dalam Islam," pengantar dalam Nasaruddin Umar, Argumen Kesetaraan Jender Perspektif Al-Qur'an (Jakarta: Paramadina, 2001)

46 Baraja, Gambaran Global Pemerintahan,

47 Bruce B. Lawrence, Menepis Mitos, Islam Dibalik Kekerasan? (Jakarta: Serambi, 2002), h. 17

48 Lihat Riffat Hassan "Is Islam a Help or Hindrance to Women's Development?" dalam Johan Meuleman (ed.) Islam in the Era of Globalization, h. 136.

49 Francis Fukuyama, Kemenangan Kapitalisme dan Demokrasi Liberal (Yogyakarta: Oalam, 2001)

\section{DAFTAR PUSTAKA}

Ahmed, Akbar S. 1997. Living Islam: Tamasya Budaya Menyusuri Samarkand hingga Stornoway. Jakarta: Mizan

Aldridge, Alan. 2008. Religion in the Contemporary World. Cambridge: Polity

Al-Maududi, Abul A'la. 1984. Khalifah dan Kerajaan. Bandung: Mizan

Amstrong, Karen. 2004. Islam: A Short History Sepintas Sejarah Islam. Surabaya: Ikon Teralitera

Baraja, Abdul Oadir. 2001. Gambaran Global Pemerintahan Islam. Surabaya: RAP

Bellah, Robert N. 2000. Beyond Belief Menemukan Kembali Agama: Esai-esai tentang Agama di Dunia Modern. Jakarta: Paramadina

Burleigh, Michael. 2007. Earthly Power: The Clash of Religion and Politics in Europe From the French Revolution to the Great War. Australia: Harper \& Collins

Davis, Charles Davis. 1994. Religion and The Making Society: Essays in Social Theology. Cambridge: Cambridge University Press

Fukuyama, Francis. 2001. Benturan Islam dan Modernisasi. Koran Tempo 26, 11

Gellner, Ernest. 1981. Muslim Society. Cambridge: Cambridge University Press

Giddens, Anthony. 1985. Kapitalisme dan Teori Sosial Modern: Suatau Analisis Karya Tulis Marx, Durkheim dan Max Weber. Jakarta: UI Press

Hassan, Riaz. 20

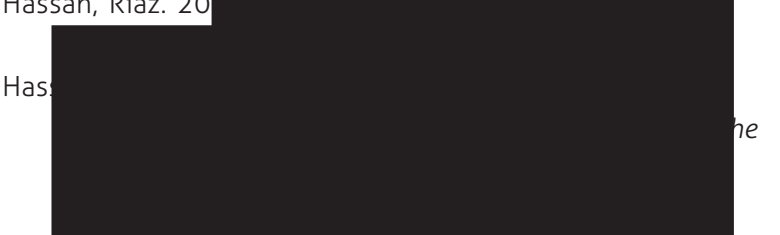

Heikal, Muhammad Husein. 1993. Pemerintahan Islam. Jakarta: Pustaka Firdaus

Herriot, Peter. 2009. Religious Fundamentalism: Global, Lokal, Personal. London: Routledge

Ismail, Faisal. 1999. Ideologi Hegemoni dan Otoritas Agama: Wacana Ketegangan Kreatif Islam dan Pancasila. Yogyakarta: Tiara Wacana

Jamhari dan Jajang Jahroni, (ed). 2004. Gerakan Salafi Radikal di Indonesia. Jakarta: Rajawali Press

Juergensmeyer, Mark. 1998. Menentang Negara Sekuler: Kebangkitan Global Nasionalisme Religius. Bandung: Mizan

Kepel, Gilles. 1997. Pembalasan Tuhan: Kebangkitan Agama-agama Samawi di Dunia Modern. Jakarta: Pustaka Hidayah

Lawrence, Bruce B. 2002. Menepis Mitos, Islam Dibalik Kekerasan?. Jakarta: Serambi

Maarif, Ahmad Syafii. 2009. Islam dalam Bingkai Keindonesiaan dan Kemanusiaan: Sebuah Refleksi Sejarah. Bandung: Mizan

Mahendra, Yusril Ihza. 1999. Modernisme dan Fundamentalisme dalam Politik Islam: Perbandingan Partai Masyumi (Indonesia) dan Partai Jama'at-i-Islami (Pakistan). Jakarta: Paramadina

Marranci, Gabriele. 2008. The Anthropolgy of Islam. Cambridge: Berg

Meij. Dick van der. 2003. Dinamika Kontemporer dalam Masyarakat Islam. Jakarta: INIS

Moaddel, Mansoor. 1998. "Religion and Women: Islamic Modernism versus Fundamentalism." Journal for the Scientific Study of Religion, Vol. 37, No. 1

Nasution, Harun dan Azyumardi Azra. 1985. Perkembangan Modern Dalam Islam. Jakarta: Yayasan Obor Indonesia

Nooris, Pippa dan Ronald Inglehart. 2009. Sekularisasi Ditinjau Kembali: Agama dan Politik di Dunia Dewasa Ini. Jakarta: Paramadia dan Alvabet

Osman, Fathi. 1996. "Bay'ah al-Imam: Kesepakatan Pengangkatan Kepala Negara" dalam Mumtaz Ahmad, ed. Masalah-masalah Teori Politik Islam. Bandung: Mizan

Pranowo, M Bambang. 1998. Islam Faktual: Antara Tradisi dan Relasi Kuasa. Yogyakarta: Adicita

Sayyid Quthub, 1987. Petunjuk Jalan, Jakarta: Media Dakwah. Cet 3.

Sjadzali, Munawir. 1990. Islam dan Tata Negara: Ajaran, Sejarah dan Pemikiran. Jakarta: UI Press

Sukardja, Ahmad. 1995. Piagam Madinah dan UUD 1945: Kajian Perbandingan Tentang Dasar Hidup Bersama Dalam Masyarakat Majemuk. Jakarta: UI Press

Umar, Nasaruddin. 2001. Argumen Kesetaraan Jender Perspektif Al-Qur'an. Jakarta: Paramadina

Voll, John Obert. 1982. Islam: Continuity and Change in The Modern World. Colorado: Westview Press

Woodward, Mark R. 2005. "Modernity and The Disenchantment of Life: A Muslim-Christian Contrast" dalam Johan Meuleman, (ed.) Islam in the Era of Globalization: Muslim Attitude Towards Modernity and Identity. London: Routledge 